\title{
Emailing in English Writing: a $A$ Case Study Towards Students in Two Classes at SMA Negeri 1 Sinjai
}

\author{
Meta Mutiamiftah \\ metamutia808@gmail.com \\ Haryanto Atmowardoyo \\ aharyanto_fbsunm@yahoo.co.id \\ Baso Jabu \\ basojabu@unm.ac.id \\ Graduate Program, State University of Makassar
}

\begin{abstract}
This article explores the reasons of the students for emailing activities and how emailing activities influence the student' writing competence. It also discusses emailing support the students writing competence at SMA Neg 1 Sinjai. This article applied a qualitative method, covering the collection, analysis, and interpretation of comprehensive narrative and visual data in order to gain insights into a particular phenomenon of interest. The participants of this article were the second year students of SMA Negeri 1 Sinjai, consisting of 10 students chosen from two classes using purposive sampling. The data of this research were collected through observation with simple protocol. The data were analyzed using the grounded theory technique, including three types or stages of data analysis; ; call open coding, axial coding, and selective coding. The result of this research reveals the student's reasons for s do emailing activities, that is because it is interesting to do, comfortable, fast, and usable to send many file. Then, raising the habit of using English language when writing in email, improvest their writing competence. And the English teacher claimsed that email as a learning tool is beneficial in to increasing of the students grades gradesin English language subject.
\end{abstract}

Keywords: emailing, English writing, case study, two classes

\section{INTRODUCTION}

There are some factors that influence the students' writing ability, such as vocabulary, and interesting topics for the students in learning writing, and interesting method. Nurzaitun (1996) states that the teacher should have many methods to apply in teaching writing. Many teachers do not try to make their class interesting with various methods, materials to stimulate learning of language skills effectively. The teachers must be able to apply method that can stimulate students to write, one way to treat this is through email. There are many methods to make students interested in improving their writing ability. One of them is by using technology. And one of the famous programs in technology is internet. The internet is one of technology which is often applied in supporting improvement in various areas, 
like education. The advancement of the Internet and the wide spread of technology in our | life creates new opportunities for language learning. Since most of the Internet content is in English, the English teacher gains access to the enormous variety of authentic materials relating to all spheres of life at almost no cost. Especially in non-English speaking countries, and how the Web is the invaluable source of information, both for teachers to create classroom materials and for their classes to explore the whole world just by clicking the mouse.

In education there are many kinds of internet application which can be applied. "There are five applications in standard internet which need to be applied in education: that is E-mail, Mailing list (list milis), News Group, File transfer, Protocol, and World Wide Website (WWW) (Purbo, 2004). E-mail, a form of asynchronous computer-mediated communication, has been called "The mother of all Internet applications " (Warschauer, et al, $2000: 3$ ).

E-mail application is often conceived as electronic E-mail and this application can help students' improve their writing ability. Belisle (1998) argued that E-mail helps students in their writing class, and a teacher has a lot of work to do, help students' in improved their writing ability. Sometimes other time-consuming thing like organizing, filling, retrieving and replying to the students' writing can take away in important time for teaching and if the students' use E-mail in the writing class, the used of a so-called filtering and stationary can be a big help and save a lot of time important things, like the actual teaching of writing.

It can be concluded that many influence factors in achieving the learning activities. One of them is a technology, which can be used in education and learning activities. Because learning by a technology application such as process and product use information and communication technology (Information and Communication Technology /ICT) to solve the problems of education has many benefits or advantages. Then considering the advantages by learning technology, can improve the quality, efficiency, and effectiveness of education and learning at all levels including senior high school including use email application.

Based on the background, the researcher interested in examining used of computer technology by focusing on using email application, by students' of SMAN 1 Sinjai in influence the students writing competence, and email application support their writing competence in English language. The results of this study are expected to provide theoritical and practical information with an expectation to be useful input in teaching process, because based on this research the students' can broaden their knowledge about internet application and important to make conclusion decision for the influence of development technology, also support to make teaching learning process success while considering the students' need.

Definition about writing from some expert. Writing is one way to convey something about ourselves to communicate ideas to people beyond immediate vicinity, to learn that we did not know (Trimmer and Summer, 1993:10). Basically, writing means producing or reproducing message a written language. It involves an active process to organize and formulates ideas on the paper, so the reader can follow the writer messages as well as in 
oral form. Writing is production of graphic symbols to forms words sequences of sentence arranged in particular order and linked together. Writing also is a process of encoding messages to transfer meaning to reader (Byrne, $1990: 1$ ), and writing is progressive activity. It means that when we start to write something, we have already been thinking about the idea that we are going to write in our composition (Oshima and Hague, $2006: 2$ ).

Email application is an information and communication technology. It uses technology to communicate a digital message over the internet. And it is one of the internet thast casn be used for education. There are many reasens why using e mail is advantageous for the student and the teacher in the writing class. By using e-mail in the writing class students become familiar with a communication tool that is vital to their survival in the $21^{\text {*t }}$ century. In the world of business, polities, and technology, and especially in education, electronic mail is quickly taking the place of voice, paper, and fax commmnication. Employers will require this vital skill for their employs of today and tomorrow. And a teacher can interact with a student or a group of students' working on a project at times that are more convenient to the student, group, and the teacher. The vital interaction and feedback that takes place between a teacher and student ( or group of students') over a writing task is not limited to the confines of a classroom. The last, the positive aspect of e-mail is that shy students' have a forum for expressing themselves and asking questions. Occasionally, some students' who do not like to express themselves with writing. Since students' usually generate more content electronically than with traditional pen and pencil methods, shy students' often tend to express their opinions more openly without fear. This can give students' self confidence and eventually improve their writing ability. That's why, E-mail is different from the other correspondence application, because communication with media electronic is unique, good in the speed transfer of the data and also to broadcast. This is the fundamental reason if we want to compare communication with printed paper. Communication with printed paper, perhaps will produce sometimes clear and not always require to be clarified the content. While communication with E-mail, sometimes information in E-mail must be repeated confirmation to the sender about anything which relation the E-mail like the structure of the language, the purpose not clear, and as we know that sometimes in E-mail have the sign to make the clear what the sender mean and sign to describe the emotion of the sender.

\section{METHOD}

This study applied a qualitative method. According to Gay etal. (2006:399) qualitative research was the collection, analysis, and interpretation of comprehensive narrative and visual data in order to gain insights into a particular phenomenon of interest. The qualitative research applied a case study approach. Gay etal. (2006:402) stated that the case study approach, as the type of ethnographic research design, focusedd on the exploration of phenomenon that occurs within a bounded system. In addition, Qualitative research methods because of this study exploreded the phenomenon of emailing activities in English lesson, emailing activities influenced the students' writing competences at SMA Neg. 1 Sinjai and how emailing activities can supported the students' writing competence at SMA Neg 1 Sinjai. 
This study selected the participants by purposive sampling, from two classes in second grade at SMA Neg 1 Sinjai, to find out the reason of students used email, to find out that emailing activities influenced the students' writing competences at SMA Neg. 1 Sinjai. And to find out how email activities can supported the students writing competence with interviewed by the English teacher and the school principals.

The instruments of this study employed some instruments to facilitated this research. The first one is the researcher herself as the main instruments to collected data of observation and interview. And other helpful instruments were observation note, interview guideline.

The colleted data analyze about (1) the reason students used email , (2) email activitiy influenced the students' writing competences and (3) why email activities can supported their writing competence, by collecting data from observation, interview, school archives. Then analyzing all the data by using open and axial coding, and the last is presenting data (Johnson and Christensen, 2004: 381).

\section{FINDINGS AND DISCUSSION}

\section{FINDINGS}

Some findings dealing concern with three aspects, those aspect are : (1) The reason the students do emailing activities, (2) Does Emailing activities influence the students' witing competence, (3) How emailing activities suppost students writing competence.

\section{The reasons of why the students perform emailing activities}

In this section the reseacher describes about the students' reasons of why the students perform emailing activities.

\section{a. Important application in internet and interesting activity}

Based on the researcher observation and students interview from ten students from two classes, the resercher, find out some reasons.

Same with opinion from student stated that,

" hal yang menarik di email itu mam ada banyak tambahan yang bisa di pake kalau lagi menulis surat, misalnya bisa kie selip file mam”(A.H, 24 August 2017)

$>\quad$ "interesting things in the email mam there are many extras that can be used if again write a letter, for example can insert file mam "”(A.H, 24 August 2017)

\section{$>\quad$ The interesting thing in email, there are some additional can used in write a letter,} for example we can insert other file.

From A.H statement we can said that how email make a student interested to used because in email we can put other file, to support what we write in email.

And other student said that how email can be used for education, with email student easy to do their activict for one subject because in email we can find other knowledge. 
"menurut saya mam faktor utama yang membuat email itu menarik karena dapat digunakan dalam bidang pendidika juga, selain itu sekarang di email kita bisa mendapatkan pengetahuan baru"(IA, 24 August 2016)

"I think mam the main factor that makes email interesting because it can be used in education, besides now in email we can get new knowledge" "(IA, 24 August 2016)

$>$ I think, the main factors make email is interesting because we can also used in education and for now with email we can get a new knowledge about something.

And other statements from FI statement.

" email itu kan memang digunakan untuk menulis surat mam pada awalnya, Cuma sekarang sudah terdapat inovasi baru jadi kita sudah tidak merasa bosan untuk membuka email” (FI, 24 August 2016)

$>\quad$ "email it was indeed used to write letters at first, just now there are new innovations so we have not feel bored to open an email" (FI 24 August 2016).

$>$ Email used to write a letter, but for now we can find other inovation that make email is not bored application.

we can conclude that how email it was interesting because email not just used to write a letter but for now in email we can found the new inovation that can make students not boring when they used email in their daily life.

\section{b. Comfortable Activities}

Because we don't have to go to the post office, buy envelopes and stamps to send messages. Just sit in front of the internet-connected computer and type in our message then send to the destination address. Nowadays even we can send e-mail via mobile communication media such as mobile phones.

opinion from the JM stated that :

" kalau saya mam yang membuat email itu menarik karena email itu bisa digunakan dimana pun dan kapan pun, bahkan merupakan aplikasi awal yang harus kita ketahui dulu sebelum kita mengetahui aplikasi lainnya” (JM, 24 August 2016)

"for me, that makes the email interesting because the email can be used anywhere and anytime, even an initial application that we must know first before we know the other applications" (JM, 24 August 2016)

$>$ Email is interesting application because can use anywhere and anytime, even email is first important application must we know.

c. Fast Activitity

E-mail delivery can take place quickly, provided that the internet channels we use are not problematic. We can send e-mail to any part of the world within a few seconds, even 
minutes later we can receive a reply from the person we send the e-mail. From AP said that email is a good aplication from internet which is make easy when we want to send a letter for other people, without we didn't need a long time to send it.

" kalau menurut saya mam email itu membuat kita tidak susah lagi untuk kirim surat karena bisa dalam hitungan detik surat yang kita kirim bisa cepat sampai mam" (AP, 26 August 2016)

$>\quad$ “if I think email it makes us no longer difficult to send a letter because it can be in second a letter that a letter send quickly" (AP, 26 August 2016)

$>\quad$ With email we did not find difficult to send a letter because a letter can be send very fast.

d. Usable for sending many files

Nowadays email is not only used to send text messages (posts) only. The contents of an email can be a multimedia file that includes images, videos, programs and even sound. One of students stated that in email for now we can also send email with a big capacity or we can said that email help the writter to send other file in support their letter.

“ kalau untuk sekarang email itu selain mempermudah pengiriman surat mam, email juga memberikan fasilitas yang lain, seperti di email kita bisa mengirimkan file atau data dengan ukuran yang lebih besar" (AM, 26 August 2016)

$>\quad$ "For now the email in addition to facilitate the delivery of mail and, email also provides other facilities, such as in email we can send files or data premises larger sizes" (A.M, 26 August 2016)

\section{$>$ Besides email make easy to send a letter; email also give other facilities like send a file or data.}

Based on some statements from students we can said, that how email still have something will make student interested to used it. Because email application by the time do some of inovation to make the user not boring with the old fashion from email before. And with email the students can find other function not just for write but can do other activity.

2. Emailing activities influence the students' writing competence

For this part there was some of achievement from the students after they used email especially in study English Language.

\section{a. Raising a habit of using English language}

Based on the interviewed, found that some of the stduents' when they used email to write a letter they almost write with English language, although some of the students said that they was combined the language between Indonesia and English language. The students that used english language in wrote a letter in email, they said if they used dictionary to help them to translate in English Language. Based on MZ said that: 
" kalau saya menulis di email mam, saya kadang menggunakan bahasa inggris, tapi kalau saya menemui kesulitan dengan kosakata yang harus saya gunakan saya akan menggunakan bantuan kamus mam” (MZ, 26 August 2016)

" for me mam, I sometimes using English langueg, but if I find difficult with the vocabulary I must use dictionary to help me mam" (MZ, 26 August 2016)

If I write a letter in email, sometimes with English language but if I find difficult in vocabulary, I will use a dictionary.

In other statement some of the students they was vey comfortable if they combine between Indonesian language and English Language. Based on $\mathrm{AH}$ stated that:

“ kalau saya menggunakan email mam untuk menulis surat atau yang lainya saya kadang menggabungkan dua bahasa antara bahasa indoneisa dan bahasa inggris” (AH, 26 August 2016)

> "for me mam, when I use email to write a letter or anything, sometimes I combined between indonesian language and English Language” (AH, 26 August 2016).

$>$ Used email in write a letter with combine two languages; english language and indonesian language.

Then from other student said that write a letter in email with combined two langauges, can help to understand what they want to write. But for that reason how used English Language more than used Indonesian language. Because a students thought that email was one of the best place to practice their writing competence.

“ sama dengan yang lainnya mam, kalau saya lebih senang menggabungkan dua bahasa itu, akan tetapi di sisi lain dalam penulisannnya penggunaan bahasa inggris lebih sering, karena saya berpendapat bahwa dengan emai saya bisa mengukur saya punya kemampuan menulis khususnya dalam bahasa inggris” (PF, 26 August 2016)

$>$ " same with other mam, if I use email to write a letter I am very comfortable to combine between indonesia language and English Language, but when I write in email englsih language more than indonesian language, beacuse I think email is the best place to measure my writing competence especially in English language" (PF, 26 August 2016)

$>\quad$ same with others, if I prefer to combine the two languages, but on the other hand in writing I use of English more, because by using email I can measure my writing skills, especially in English

From the some of statement above we can said that how emailing activities influence the students writing competence in English Language after used Email. Because they think 
email is one of the good application in internet to them in measured that English writing competence.

b. Improving writing competence.

For this part, the researcher found some of the factor that maked students interesting used email especialy to influence their writing competence. Based on JM stated that:

“ karena email itu mam bisa memberikan pengaruh besar dalam hal kemauan kita untuk menulis, kalau menulis menggunakan bahasa inggris mam sudah tentu dapat melatih lagi kemampuan menulis kita mam"(JM, 24 August 2016)

$>\quad$ "because email can give big influence in writing, because if we write with English language can be practice our competence in writing mam" (JM, 24 August 2016)

D Because email can give a big influence in terms of willingness to write, when writing using English is certainly able to train again our writing ability.

And based on other student stated, how email can give a ability to them in writing a letter or anything but still used English language. The AP student stated that:

“ karena sudah ada kebiasaan mam untuk menggunakan bahasa inggris kalau mau menulis surat sama teman atau pun dengan yang lainnya” (AP, 26 August 2016)

$>\quad$ "because for now we have a ability to write a letter with use English for my friends or other" (AP, 26 August 2016)

$>$ Because it has been accustomed to using English in writing letters with friends or with others

And based on A.M stated that:

“ setidaknya sudah ada motivasi juga dari dalam diri untuk lebih meningkatkan kemampuan menulis dengan menggunakan bahasa inggris lewat email mam" (AM, 26 August 2016)

$>$ " at least we have motivation from our self to improving our writing competence with using English languge in email” (AM, 26 August 2016)

$>$ We have been motivated to further improve our English writing skills by email.

We can conclude that how emailing activities influence a students writing competence especially in English language. In email not just about how we write our expression or our felt about something, but in email we can put some of motion than can be support what we want to talked to other people, although we didn't write anything.

3. How emailing activities support the students' writing competence 
a. Emaling activties as a learning tool

In relation to learning tools, Email is generally used to send messages or tasks by teachers to students. Along with the development of technology, the learning is doing by online because in the school has been equipped with facilities that can support the occurrence of learning process online.

Based on the researcher interview the school principals about the availability of facilities that can support online learning process, such as computer laboratory and internet network. The school principals stated that:

"untuk laboratoruim komputer itu dibangun pada tahun 2005 akan tetapi nanti pada tahun 2009 baru dilakukan renovasi dari segi tempat dan fasilitas pendukung lainnya”

"for the computer laboratory was built in 2005 but in 2009 do new renovation in a place and other supporting facilities"

$>$ Computer laboratory was built in 2005 but in 2009 renovation was done in terms of place and other supporting facilities

The computer laboratory can be used by all subject teachers who want to do the learning process by online. Because the computer laboratory supported by an active computer and a good internet connection.

And also the researcher interview the English teacher to ask how far she use existing technology facilities in teaching learning process. She stated that:

"kalau sekarang sudah bagus karena sudah banyak fasilitas atau sarana yang bisa digunakan, bagus juga koneksi internetnya jadi saya bisa mengajar menggunakan fasilitas yang ada di internet, contohnya saya biasa menggunakan email untuk melihat kemampuan menulis siswa dengan memberikan tugas menulis menggunakan email, kemudian dikirim ke email saya. Dan proses itu terjadi di laboratorium komputer"

$>\quad$ "today there are many facilities that can be used. Besides that, in this school have good internet connection, so I can teach by using application in the internet, for example I used Email to see the writing competence of the students by giving the task of writing using email, then sent to my email. And the process takes place in a computer laboratory"

$>$ Laboratory conditions are good because there are already facilities that can be used, internet connection is very supportive so in the process of teaching we can use the facilities available on the internet, for example using email to see the ability to write students by giving the task of writing using email, then sent to my email. And the process takes place in a computer laboratory.

Based on the English teacher statement, we can conclude how email activities that students' do in leaning process can support their writing competence because the tasks can 
made be up to speed. In addition, the teacher can also deliver the task via Email to the students. So Email is very instrumental in the world of education.

\section{b. Increasing students' grade in English language subject}

For this part, find out data from the English teacher. The data taken from the writing competence grade. From the data we can find out, how emailing activities they do can support their writing comptence, espesially in English Language.

\section{DISCUSSION}

The significants students' do emailing activities can give a big influence. There are some factors can be conclude which consist of the students reason do emailing activities, emailing activities influence the students writing competence, and how emailing activities support their writing competence.

Talked about the students reason do emailing activities, beacuse email was important application in internet that was very interesting to do, because emailing activities not just used to write a letter but for now we can do other activities that can make students not bored when do emailing activities, and emailing activities was comfortable, because we donot have to go to the post office, buy envelopes and stamps to send messages. Just sit in front of the internet-connected computer and type in our message then send to the destination address. Nowadays even we can send e-mail via mobile communication media such as mobile phones.

Besides that, Emailing activities was fast, because E-mail delivery can take place quickly, provided that the internet channels we use are not problematic. We can send e-mail to any part of the world within a few seconds, even minutes later we can receive a reply from the person we send the e-mail.

Emailing activities useble send many files, Nowadays email is not only used to send text messages (posts) only. The contents of an e-mail can be a multimedia file that includes images, videos, programs and even sound.

Emailing activities influence the students' writing competence, with raised the habit of using English language when writing in email. Because students still felt comfortable when they write a letter or anything in email with use English Language.

Wrote in email, was interested application in internet to improve their writing competence, because as a student in the globalization era, the ability to use e-mail is very useful because e-mail is a means of global communication. And then in email not just about how we write our expression or our felt about something, but in email we can put some of motion than can be support what we want to talked to other people, although we didn't write anything.

Then how emailing activities support the students' writing competence. First, email activities as a learning tool because English teacher used email in teaching learning process because for students, email is indispensable for the delivery of school tasks. By email, 
students can collect their duties into the teacher's email. Many teachers and students today use email as a medium for collecting tasks. Students send tasks or jobs assigned by teacher through teacher's email. Email becomes a portfolio document delivery. Teachers also become easier in documenting student work through email. Second, emailing activities can increased the students grade in English language subject. Because already feel comfortable and become a habit to always write in English so that the impact on the value of students, especially for writing skills can also increase.

The finding above was done with some teory before. Where the teory are linked with use internet in teaching learning process, especially in applied emailing activities. Such as from Chao-chih Liao (March 1999) "E-mailing to Improve EFL Learners' Reading and Writing Abilities: Taiwan Experience", from this the researcher find out how emailing activities to prepare students for potential future needs to contact people who do not speak Mandarin or Taiwanese and have English as their foreign. And Email allows the students to write to English speakers from other cultures, even if English is not their native language, because in the world there seems to be more EFL and ESL speakers than native speakers.

Ron Belisle (December 1996) "E-mail Activities in the ESL Writing Class", by using email in writing class, students become familiar with a communication tool that will be vital in the 21 st century. Employers who do not already require this skill for their employees of today, will tomorrow.

Then, Margaret Gonglewski, Christine Meloni and Jocelyne Brant (March 2001), while email is now already considered a relatively "low-tech" medium, it can bring effective benefits to the process of learning a foreign language. The most important benefit is potential to offer learners opportunities for much more valuable communicative interaction in the target language than was ever possible in the traditional foreign language classroom.

\section{CONCLUSION}

Based on the results and discussion, the researcher draw the conclusions as in the following:

a. The reasons the students do emailing activities are: firstly, email is an important application in internet that is very intersting to do ; secondly, emailing activities is comfotable ; thirdly, emailing activities is fast, fourtly, emailing activities Usable for sending many files

b. Emailing activities influence the students' writing competence are firstly, raising a habit of using English language because email is one of the good application in internet to measured that English writing competence; secondly, Improving writing competence because in email the students' write their expression or their felt about something, and also in email they can put some of motion than can be support what we want to talked to other people. 
c. How emailing activities the students do support their writing competence are firstly, email activities as a learning tool because English teacher used email in teaching learning process, where email is indispensable for the delivery of school task,so by email students can collect their duties into the teacher's email; secondly, do emailing activities increased of the students grade in English language when they always do emailing activities.

The researcher suggests the teachers to consider usig internet application in teaching learning process. Because for now the development of technolgy is very fast, so teachers are challanged to use interesting method in teaching learning process. Teacher should assign their standar to do at more practicing is demonstrate how to apply language learning in different ways whether in the classroom context or out of the classroom context like in computer laboratory. It is suggested to the further researchers to conduct more comprehensive investigation on wide range of the factors or variables affecting language learning strategies employed by the EFL students, particularly Indonesian learners.

\section{REFERENCES}

Afrizal. (2014). Metode Penelitian Kualitatif (Sebuah Upaya Mendukung Penggunaan Penelitian Kualitatif dalam Berbagai Disiplin Ilmu). PT. Rajagrafindo Persada. Jakarta.

Akkaya, Aslihan. (2002). Students"'-teacher interaction:pragmatic markers of gender, nationality and status of the students'.' Blacksea Technique Univesity.

Belisle, R. (1996). E-mail activities in the ESL writing class. The Internet TESL Journal http://iteslj.org/Articles/Belisle-E-mail.html

Belisle, R. (1998). Let the email software do the work: time savig features for the writing teacher. The Internet TESL Journal http://iteslj.org/Articles/Belisle-E-mail.html

Brown, H.D. (1994). Principles of language learning and teaching. London: Prentice-Hall. Inc.

Creswell, J. W. (1994). Research design: Qualitative \& quantitative approaches. Thousand Oaks, CA: Sage Publications.

Dakhalan, Muhammad. (2014). Factors influence the students' achievement in English language learning ( A case study of class VII-3 in MTsN Mangempang Barru).Makassar: Pasca Sarjana UNM.

Fox, Gerald. (1998). The internet : making it work in the ESL classroom. http://iteslj.org/Articles/Fox-Internet.html. The Internet TESL Journal, Vol. IV, No. 9, September 1998

Gonglewski, Margaret., Meloni, Christine., Brant, Jocelyne. (2001). Using E-mail in Foreign Language Teaching: Rationale and Suggestions. The George Washington University (Washington DC, USA).. http://iteslj.org/Techniques/Meloni-Email.html. 
Graves, Donald H. 1983. "The growth and development of first-grade writers." Dalam Freedman, Aviva et al., Learning to Write: First Language/Second Language. London: Longman Group, Ltd

Greenfield, Roseanne. (2003). Collaborative E-mail Exchange for Teaching Secondary ESL: A Case Study In Hong kong.. Hong Kong University, School of Professional and Continuing Education. Language Learning \& Technology Vol. 7, No. 1, January 2003, pp. 46-70.

Kap, Eui. (1998). Using E-mail in EFL Writing Classes. Science High School (Seoul, Korea). The Internet TESL Journal, Vol. IV, No. 11.

Krajka, Jarek Krajka. (2000). Using the Internet in ESL Writing Instruction. Stefan Batory Pallottine Secondary School (Lublin, Poland), Adam. http://iteslj.org/Techniques/Krajka-WritingUsingNet.html

Liaw , Meei-Ling. (2003). Cross-Cultural E-Mail Correspondence for Reflective EFL Teacher Education . Taichung, Taiwan, TESL-EJ Journal, Vol. 6, No.4.

Liofeng, Chia, Chao-Chih. (1999). E-mailing to Improve EFL Learners' Reading and Writing Abilities: Taiwan Experience. University (Taichung Taiwan). http://iteslj.org/Articles/Liao-E-mailing.html

Mudzakir, Djauzi. (Yin K, Robert. 2002). Studi kasus (desain dan metode). Massachutsetts Institute of Technology, U.S.A.

Nagel, Pieter. (1999). E-mail in the Virtual ESL/EFL Classroom. Nagelp [at] unin.unorth.ac.za. http://iteslj.org/Articles/Nagel-E-mail.html

Nurzaitun. (1996). The ability $t$ write an English composition through parallel writing technique. A case study on the third grade students of SMU 8 Ujuang pandang. Ujung pandang: theisis FPBS IKIP Ujuangpandang.

Smalley, R. L., Ruetten, M. K., \& Kozyrev, J. R. (2001). The writing process. In Refining Composition Skiils: Rhetoric and Grammar (pp. 3-9). Boston: Heinle \& Heinle.

Sugiyono. (2011). Metode Penelitian Kombinasi (Mixed Methods). Alfabeta. Bandung.

Tan, et al. (1999). Using cooperative learning to integrate thinking and information technology in a content-based writing lesson. http://iteslj.org/ The Internet TESL Journal, Vol. V, No. 8, August 1999

Terminello, Verna and Reed, Marcia G.NetEffect Series: E-mail Communicate Effectively. New Jersey: Prentice Hall, 2003.

The Writing Center at UNC Chapel Hill (2012), Effective E-mail Communication. College of Art and Science

Robb N, Thomas. (1996). E-Mail Keypals for Language Fluency. Kyoto Sangyo University. This article appeared originally in Foreign Language Notes (Foreign Language Educators of New Jersey), Vol 38, No. 3, pp 8-10.

Rosseti, Paolo. (1998). Gender Differences in E-mail Communication. Vancouver, Canada. http://itesli.org/Articles/Rossetti-GenderDif.html

Warschauer, Mark. (1995). E-Mail for English Teachers:Bringing the Internet and Computer Learning Networks into the Language Classroom. Alexandria VA: Teachers of English to Speakers of Other Languages. TESL-EJ Journal, Vol. 2, No.1. 
ELT Worldwide Vol 5 No 2 (2018)

Mutiamiftah, Atmowardoyo, Jabu : Emailing in English ...

Warschauer, M. (1995). E-mail for English teaching. Bloomington, IL: Teachers of English to Speakers of Other Languages (TESOL).

Ybarra, Renee. (2003). Using Technology to Help ESL/EFL Students' Develop Language Skills. C.C. Lambert Elementary (Tustin, California, USA). http://iteslj.org/Articles/Ybarra-Technology.html 